\title{
Translating Idiomatic Expressions from Arabic into English in Essam Youssef's $A$ Quarter Gram: Challenges and Strategies ${ }^{(*)}$
}

\author{
Rania Allam \\ Lecturer, Faculty of Languages, \\ MSA University, Egypt
}

الملخص

ترجمة التعابير الاصطلاحية من العربية إلى الإجليزية في رواية عصام يوسف ربع جرام: التصديات والاستر|تيجيات

التعابير الاصطلاحية في حد ذاتها عبارة عن وحدات لغوية ذات جوانب دلالية


للمقاطع الاصطلاحية وخاصة فى النصوص الأدبية. تهدف هذه الورقة البهة البحثية إلى تحليل

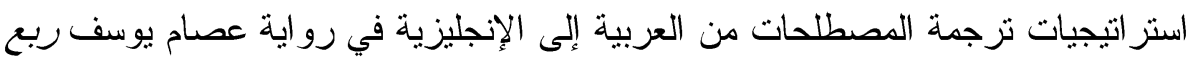

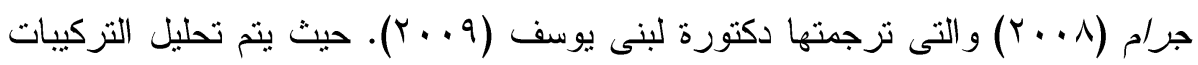

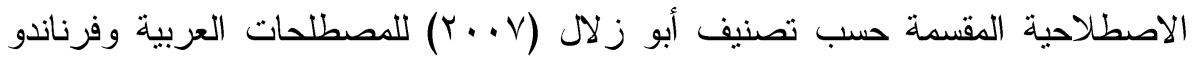

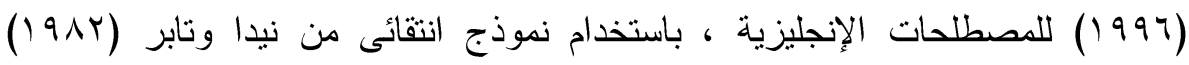

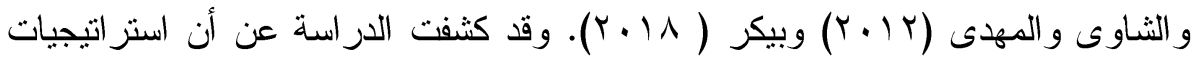

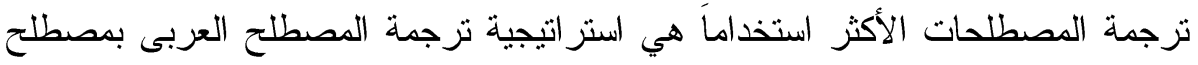

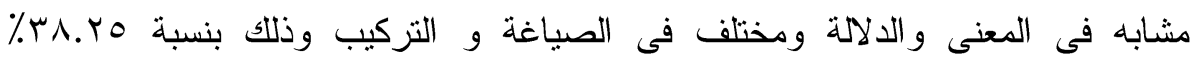

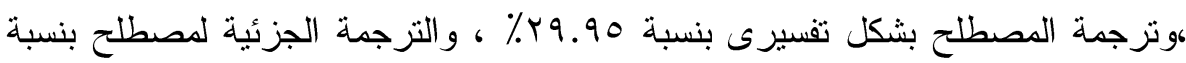

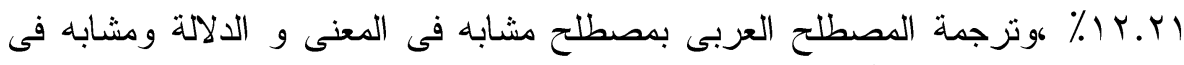

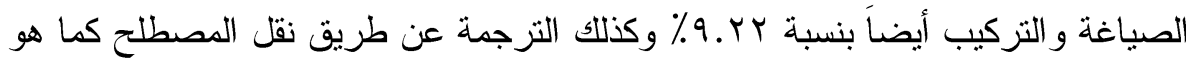

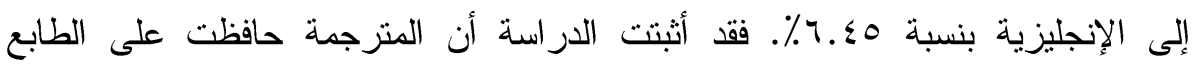

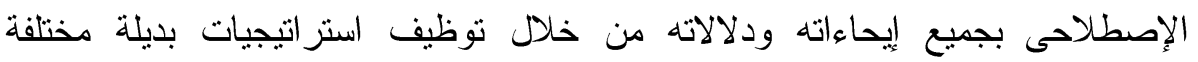
للمصطلح الموجود بالنص العربى. لإهلى

${ }^{(*)}$ Bulletin of the Faculty of Arts Volume 79 Issue 4 Arpil 2019 
الكلمات المفتاحية: تصنيف التعابير الاصطلاحية، استراتيجيات ترجمة التعابير

الاصطلاحية، التزجمة باستخدام تعبير مماتل فى التركيب و المضمون ، التزجمة بإستخدام

تعبير مماتل فى المضمون ومختلف فى التزكيب ، المعنى المماتل ، نرجمة التعبير



ملحوظات تفسيرية ، الحذف. باخف

\section{Abstract}

Idioms per se are linguistic units with different semantic, pragmatic and cultural facets which pose some untranslatability challenges so as to render the closest interlingual source text (ST)-target text (TT) pairs, especially in literary texts. The present paper aims at investigating the strategies of translating idioms from Arabic into English in Essam Youssef's A Quarter Gram (2008) ربع جرام translated by Loubna Youssef (2009). The analytical decoding process for the idiomatic structures is classified according to Abou-Zalal (2007) for the Arabic idioms and Fernando (1996) for the English ones, using an eclectic model of Nida and Taber (1982), Al-Shawi and Mahadi (2012) and Baker (2018). It reveals that the most employed strategies are the strategy of using an idiom of a similar meaning but dissimilar in form $(38.25 \%)$, translation by paraphrase $(29.95 \%)$, partial translation of the idiom $(12.21 \%)$, using an idiom of similar meaning and similar form $(9.22 \%)$ and borrowing the SL idiom $(6.45 \%)$. The study exhibits the translator's keenness to retain the idiomaticity of the ST with all its implications by employing different idiomatic rendering strategies actualizing both faithfulness and acceptability of the TT.

Keywords: translational strategies of idioms, translating similar meaning and form idiom, translating similar meaning but dissimilar form idiom, translating nonidiom by idiom, paraphrase, borrowing and omission.

\section{Introduction}

Translation is an operative tool of crossing borders among different cultures and communities. However, substantial challenges can deter such process. Idioms are among such hindrances which face the translational process. The present paper aims at investigating the 
strategies and techniques of translating idioms from Arabic into English in Essam Youssef's best seller A Quarter Gram (2008) ربع translated by Loubna Youssef (2009). Idioms per se are linguistic units with different semantic, pragmatic and cultural facets which pose some untranslatability challenges so as to render the closest interlingual source text (ST)-target text (TT) pairs. In literary texts idiomatic expressions convey inexhaustible, thorough and aesthetic hues. A pertinent decoding process for the peculiar contextual meaning of the ST idiomatic structure is needed first. Second, a pragma-syntactic deciphering process is applied to grasp the cavernous connotation of the ST idiom in the literary fabric of the novel, which is already prolific in case of A Quarter Gram. How such idiomatic components with their lingua, socio-cultural hues are rendered with equivalent TT constituents is the focus of the present study.

\section{Research Objectives}

The present study aims to probe the translation of idiomatic constituents in literary context from Arabic into English, in E. Youssef's A Quarter Gram (2008). The main problems and difficulties encountered by the translator on the linguisticand cultural levels to retain idiomaticity to a certain extent are investigated within the fabric of the novel under study.

An eclectic model of translational strategies of problem solving and manipulation procedures suggested by Nida and Taber (1982), AlShawi and Mahadi (2012) and Baker (2018) to translate the different ST classifications of idioms is prodded to see to what extent they are employed in the TT fabric and for what end. Such translational strategies of either keeping or discarding idiomatic aspects can have many linguistic, socio-cultural, and aesthetic repercussions on the TT that need to be explored.

\section{Research Questions}

The study aims at posing certain questions that are supposed to 
be answered by the end of the study. They can be summarized as follows:

1. What are the translational problematic challenges facing the translator in rendering the idiomatic expressions from Arabic into English?

2. What translational strategies are employed by the translator L. Youssef to overcome the problematic challenges raised by idiomaticity in the ST?

3. To what extent are such strategies valid in rendering the idiomatic expressions in the produced TT?

4. What are the propositional repercussions, connotative implications and aesthetic effects actualized by the adopted strategies of translating idiomatic constituents?

\section{Data of Study}

The data under study is E. Youssef's best seller ربع جرام (2008) translated by Dr L. Youssef into A Quarter Gram (2009). The novel is written in Modern Standard Arabic (MSA) in its textual part. There is a tactful code-switching between colloquial Cairene Arabic (CA) in the dialogic part of the novel and MSA within its textual fabric. This poses another level of translation difficulty to echo the two varieties of source language (SL) into appropriate English target language (TL) levels.

A Quarter Gram is a prolific novel of 640 pages which presents a realistic account of the struggle of some youngmen with drug addiction. The novel is a plethora of scenes which embrace psychological, sociological and cultural hues about the lives of the main protagonist Salah and his group of friends who are all quarries of different types of drug addictions. The novel "humanizes drug addicts and conveys their suffering, lifting the veil of criminality and shame through which they are typically regarded" (Abou el Magd, 2008). In doing so, the novel displays supple code-switching between colloquial MSA and CA with a group of idioms in both varieties. Consequently, 
this poses another level of translation difficulty. The focus of the study lies in analyzing the rendering of idiomatic expressions of both varieties of Arabic to the English TT.

\section{Methodology}

The study applies a descriptive qualitative and quantitative approach employing an eclectic model of translational strategies, through the analysis of the idiomatic translational pairs in the ST and the TT. The methodological research steps can be described as follows:

1) A pertinent, selective process for the peculiar ST idiomatic structures according to the syntactic classification of Abou-Zalal (2007) for idiomatic expressions in Arabic with the aim of revealing the most useful and practical strategies followed by the translator to overcome the different translational hindrances in the TT.

2) A pragma-syntactic, descriptive qualitative deciphering process for the equivalent TT idiomatic segments is to be carried out according to Fernando's (1996) classification of idiomatic expressions.

3) A qualitative analysis of the translational process is conducted according to the strategies propounded by Baker (2018) for translating idiomatic structures together with strategies proposed by Nida and Taber (1982) and Al-Shawi and Mahadi (2012) as tool kits for analyzing the idiomatic translational pairs in the ST and the TT.

4) A quantitative analysis is performed on the idiomatic translational pairs in the ST and the TT to reveal the percentages by which the translational strategies are employed.

5) Pragma-semantic postulations and lingua-aesthetic implications about the type of translation adopted in the process, and consequently the type of the produced TT can be deduced from such qualitative-quantitative analysis conveying the overall effect of the translation on the target recipient (TR). 


\section{Theoretical Background}

\subsection{Definition of Idioms}

A lot of attempts have been made to define idioms, with all their peculiar aspects. However, there is no consensus on an exact definition. For instance, Ghazala (2003) defines idioms as "special, metaphorical, fixed phrases whose meanings and forms are not negotiable" (p. 7). Funtek (2015) defines idioms as multi-word lexical items "which are formed by two or more words to bring forth a new idea. They form an inseparable unit of a greater meaning" (p. 2). This definition is agreed upon by Crystal (2008) as well as Saberian and Fotovatnia (2011) who all agree that idiomatic structures are most of the time multi-word with rather a fixed form, bear a unified, connotative meaning. Nonetheless, the idea of non-literalness of idioms is not absolute, as Fernando (1996) describes idioms as "conventionalized multiword expressions that are often but not always non-literal" (p. 1).

Baker, whose model is the basic tool kit of the present study, defines idioms as " frozen patterns of language which allow little or no variation in form and, in the case of idioms, often carry meanings which cannot be deduced from their individual components." (2018, p. 69). Thus, translating them depending on the literal meaning of their constituent words separately would be rather pointless.

\subsection{Properties of Idioms}

Idioms, as fixed expressions, have morpho-syntactic and semantic characteristics that make them quite peculiar linguistic manifestations. Moon (1998) introduces the idea of figurative or metaphorical nature of most idioms as well as semantic opaqueness (inability to discern the idiom meaning from its lexical constituents). Glucksberg (2001) rephrases this calling it compositionality which can fully or partially be actualized in idioms according to their types. $\mathrm{He}$ also discusses syntactic formation (the dependence of an idiom meaning on its syntactic form, and its openness to syntactic analysis 
and transformation) (p. 68). Therefore "idioms are limited in the kinds of variability they are able to demonstrate" (Ifill, 2002, p. 2). Such inflexibility of variableness includes syntactic form and lexemic configuration.

Kavka (2003) pinpoints the properties of proverbiality and informality of idioms. Proverbiality includes the cultural tradition of inherited wisdom of any linguistic community explaining situations of particular social interests. Informality means the relative informal and colloquial contexts of idiomatic usage (p. 18). This is in addition to the metaphorical properity of idioms, which includes figurative language, retained in their fixed constituent components as unified phraseological units (Almahmood, 2014, p. 10).

Another aspect to be considered in translating idioms is the idea that they are culture-bound; with peculiar cultural associations, rendering them even more challenging for translators (Howwar, 2013, p.3). Accordingly, in terms of culture specificity, the correct use of the level of idiomaticity according to Irujo is quite crucial in the translation process, as "idioms vary in formality from slang (you got it) and colloquialisms (he kicked the bucket) to those which can be used in formal situations (run the risk)" (1986, p. 237).

\subsection{Translating Idioms}

Elgobshawi (2018) believes that the idiosyncrasies of idioms create many challenges in the process of dealing with and translating idioms. Similarly, Ghazala (2003) thinks that although the concept of translating idioms is rather neglected in translation studies, it is "one of the most intricate topics in the field of translation is idioms" ( $p$. 203). As two different languages having huge morpho-syntactic as well as semantic differences, English and Arabic do not display litheness in the process of rendering idioms.

Davies (2004) and Baker (2018) agree upon some points in considering difficulties of translating idioms. For instance, recognizing the SL translational segment as an idiom in the first place 
then finding an exact TL equivalent can pose a problem. Finding a TL equivalent yet used in a different connotative and referential TL meaning is another difficulty. Besides, the employment of the ST idiom in the ST literally and/or idiomatically can pose another level of difficulty as the SL and the TL do not share the exact syntactic and semantic system. Finally, the different levels of formality use in written or spoken discourse as well as the idiom frequency in the SL and the TL can be quite problematic in the translation process. Therefore, a task of a competent translator of idioms is to "compare and assess the geographical, historical, social and cultural aspects of two language communities", and develop "strategies to bridge the gaps between different cultures" (Klaudy, 2003, p. 175).

\subsection{Effect of Idioms in English and Arabic}

The idea of rendering the idiomatic elements by either preserving or discarding them may have quite a notable impact on the produced TT. By attempting to retain the idiomaticity of a ST, the translator reifies many aspects in his TT, especially a literary one with different social and cultural hues as in the case of the novel under study. Retaining the ST idiomatic structures achieves what Newmark (1988) calls the level of naturalness convenient for every type of situation (p. 24). Besides, idioms exhibit "religious beliefs, culturespecific items, superstitions, and different ideologies of the people from diverse societies and nations. They are necessary to any language in order to keep the local and cultural color of that language" (Oualif, 2017, p. 23). Accordingly, in order to achieve the TR's acceptability, the TT must preserve some if not all of the ST idiomatic portrayal, so as to attain the same impact in the target culture (TC).

Maxos (2003) puts forward that the majority of idioms are used interchangeably between spoken and written discourse but they are mostly associated with spoken discourse and therefore, 60 to 70 percent of idioms are associated with spoken language (p. 4). As a literary text A Quarter Gram, with its two varieties of Arabic in the 
written and spoken parts, display what Carine (2005) and Dweik and Abu Shakra (2011) agree upon; namely artistic impact of liveliness, richness, rhetoric and magniloquence of idiomatic expressions. The focus of this paper is to probe to what extent the TT conveys such traits.

\subsection{Classification of Idioms in English and Arabic}

McPherron and Randolph (2014) assert that although idioms delineate more vivid descriptions than nonidioms, they are not easily classified. Many attempts have also been made to classify idioms according to many criteria. However, the most pertinent to the present study is the semantic criterion of classification for English target idioms (TIs). As, Kavka and Zybert (2004) indicate that "idiomatic expressions are based on semantic rather than lexical grounds" (p. 55). One of the rather early attempts to classify idioms is that of Fernando (1996) who classifies idioms into three categories; pure idioms whose figurative meaning cannot be inferred from its constituting lexemes like: spill the beans (tell a secret), semi-idioms which some of their parts can be construed literally like: to pay the bill and literal idioms whose meaning can be readily conceived from the combination of their individual words like: on foot and of course (p. 35). This semantic classification is the one to be adopted in the present study in classifying the English TIs, as being quite revealing and more readily to explore both the semantic and pragmatic connotations of the contextual function of the TIs. Correspondingly, Glucksberg (2001) and Kvetko (2009) classify idioms by the degree of their transparency (inferring the connotative meaning from the constituting lexemes). They divide idioms into opaque or demotivated idioms and transparent compositional or partially motivated idioms.

Arabic idioms constitute a prominent position in the Arabic Rhetoric since it is a constituent part of the Qur'an, Classical works and Arabic literary heritage. Like any other language, fixed idiomatic expressions play a significant role in Arabic, as "they abound in 
classical Arabic, modern standard Arabic as well as in all of the various dialects across the Arab world" (Ali and Al- Rushaidi, 2016, p. 191). Contemporary Arabic linguistics displays a notable concern for the study of idioms, in which "idiomatic expressions are recognized as a linguistic category with its own name and features" (Almahmood, 2014, p. 44).

Many attempts to classify Arabic idioms have also been made. However, the one to be adopted in the selection of the source idioms (SIs) is the one proposed by Abou-Zalal (2007). The classification depends on a structural, numerical basis. This rather syntactic classification renders the SI selection more systematic and diverse. For the idiomatic expressions of the ST, if classified semantically would not yield the same analytical diversity, as they mainly fall in the category of the transparent (literal) or semi-opaque (partially literal) type of idioms. Abou-Zalal (2007) classifies Arabic idiom syntactically as follows: one-word idioms like: الأبرص (the moon), incomplete phrasal idioms like: آكلة اللحم (knife) and finally complete sentence idioms like: جاء لابسأ أذنيه (He was curious).

\subsection{Strategies of Translating Idioms}

As mentioned before, idioms pose some difficulties in the translational process. This is due to "the semantic, syntactic and pragmatic complexity of idiomatic expressions" which poses remarkable challenges to translators translating from and/or into a certain language (Aldahesh, 2013, p. 23). Therefore, SL Idioms stipulate certain translational manipulation according to certain strategies so as to be rendered both faithfully and acceptably in the TL. Accordingly, "strategies are necessary because they usually enable translators to overcome difficulties that they might encounter in the process of translation" (Dweik and Thalji, 2016, p. 120).

Nida and Taber are among the earliest scholars who tackled the concept of translation strategies-although they called them semantic adjustment or procedures. They put forward three translation 
adjustments for idioms: "(a) from idioms to nonidioms, (b) from idioms to idioms, and (c) from nonidioms to idioms. Frequently idioms are shifted to nonidioms in the process of transfer" (1982, p. 106) (Bold is added). Thus, they propose that although the ideal transfer is to try to translate an idiom by another, however, resorting to transferring idioms into semantic renderings other than idioms is more frequent. Therefore, opting for the most convenient strategy depends on the translator's competence.

Similarly, Baker (2018) implies that employing the right TL phraseology, natural collocations, idioms and fixed expressions momentously enrich the readability of the produced TT. Accordingly, "getting this level right means that you will avoid unintentionally producing a text that feels 'foreign"” (p. 86). This entails obviously a profound cultural and social perception of both the SL and the TL on the part of the translator so as to attain a precise, appropriate idiomatic interpretation. Moreover, Bahumaid (2010) pinpoints that "problems of interpreting idioms will be further augmented if the cultures of the SL and TL are far apart from each other as in the case of Arabic and English" (pp. 103-104).

Baker thus, propounds some strategies for translating idioms in particular, which can be summarized as follows:

\section{(1) Using an idiom of similar meaning and similar form}

This strategy implies substituting the SL idiom by an equivalent TL one which has meticulously the same meaning and virtually equivalent lexical items. However, Baker advocates that this strategy cannot be recurrently attained, as determining the right ST type, genre, style, rhetorical effect and target readership, while trying to pin down the same structure and lexical items is not an easy task. This task becomes more difficult among dissimilar language systems like Arabic and English. Hence, the ideal idiom-idiom matches can rarely be achieved. 


\section{(2) Using an idiom of similar meaning but dissimilar form}

The second strategy is that of trying to find an equivalent TL idiom even if in different lexical and syntactic fabric. Finding an idiom with similar meaning but dissimilar form, although cannot be readily achievable yet is not unattainable, as "idiomaticity is considered a common feature in all languages" (Ali and Al- Rushaidi, 2016, p. 190).

\section{(3) Borrowing the source language idiom}

Although this strategy is not common in the realm of idiomaticity, some translators adopt such strategy to evade the dilemma of retaining SL idiomatic expressions. However, it sometimes results in what Ghazala (2003) calls "abortive idiomaticity" (p. 222), which in spite of being the least creative strategy (preserving the SL idiom as it is in the TL with no change, sometimes even by transliteration), yet it needs to be inculcated as a constituent part of the TL.

\section{(4) Translation by paraphrase}

Baker thinks that this strategy is the most recurrent in translating idioms in cases of difficulty in finding a corresponding TL idiom or inappropriateness of using idiomatic structures for stylistic considerations. Paraphrasing does not always involve explaining the meaning of individual idioms, but rather replacing the referential, pragmatic meaning of the SL by another TL connotative referent.

\section{(5) Translation by omission of a play on idiom}

This strategy plays on interpreting only the literal meaning of the idiom in a context of employing the playful usage of language.

\section{(6) Translation by omission of entire idiom}

This implies the entire deletion of the ST idiom from the TT. This omission can be attributed to many reasons, for example, the absence of a close TL equivalent or a paraphrasing item, the unimportance of idiom in the context of the ST or its recurrent 
repetition that may render the TT rather redundant. Baker does not consider omission to be a dire strategy but in some instances, where the connotative meaning implied by the idiom is not fundamental in the structure of the TT and translating it would only divert the TR's attention. Similarly, Ghazala (2003) thinks that sometimes it is not the fault of the translator to omit the SL idiomatic expression, if the TL has no equivalent. Nonetheless, a compensatory strategy should be applied.

\section{(7) Strategy of compensation}

This strategy simply means that the translator can discard with the idiomatic expression at a certain point in the TT, to be later compensated or explained at later points within the fabric of the TT.

(Baker, 2018, pp. 77-87).

Further translation strategies can be proposed, in case the translator may not be able to provide a perfect TL idiom. For instance, Al-Shawi and Mahadi (2012) propose two extra strategies for translating idioms namely; using notes so as to explain enigmatic cultural aspects that can be problematic for the TR and consulting informant who has a profound knowledge about SL idioms.

\subsection{Review of the Literature}

A lot of studies tackle the idea of idiomaticity either in one language or comparably among languages. For instance, Mezmaz (2010) conducted an investigative study on the problems of nonequivalence faced by first year master students at Mentouri University Constantine in translating English idioms into or from Arabic. She attempts to identify strategies or translational solutions that might help limit such difficulties. The master students are asked to translate 12 English idioms and another 10 Arabic ones. The empirical analysis exhibits that more problems lie in the translation of idioms from English into Arabic. Besides, the study shows that students employ word for word translation as the most frequent strategy of translation 
and that the contextual milieu of the idiom help render it appropriately in the target language.

Salim and Mehawesh ( 2013) conducted a study on the translation of idiomatic expressions related to colors and their cultural specifications from Arabic into English in Naguib Mahfouz's novel The Thief and the Dogs. They explore the various translation strategies used in translating color idioms, proving that the translator employs four translation strategies namely: using an English idiom of a similar meaning and form of the Arabic idiom, translation by using cultural substitution, by paraphrasing and by omission.

Besides, in a subsequent study Kovacs (2016) explores the characteristics of idioms posing challenges for the translational process and analyses the translational strategies proposed by many scholars to decide on the appropriateness and acceptability of translated idioms in the novel of A Game of Thrones from English into Hungarian from a pedagogical point of view. The result shows that the novel is an adequate source as a teaching material. It can be used to clarify the meaning and types of idioms as well as the strategies of translating them. The study also shows how to try to deduce the meaning of idioms from the context and then try to find alternative translations of the same idiom within the same context.

\section{Analysis and Discussion}

The following sample analytical examples are divided according to the translational strategies propounded by Baker (2018), Nida and Taber (1982) and Al-Shawi and Mahadi (2012). The SIs are classified according to Abou-Zalal's (2007) classification, while the TIs are classified according to Fernando's (1996) classification. 
Rania Allam: Translating Idiomatic Expressions from Arab

6.1 Strategies of Idiomatic Expressions

6.1.1 Using an Idiom of Similar Meaning and Form

\begin{tabular}{|c|c|c|c|c|c|}
\hline $\begin{array}{l}\text { Source Idiom } \\
\text { Type }\end{array}$ & $\begin{array}{l}\text { Source } \\
\text { Idiom }\end{array}$ & $\begin{array}{l}\text { Source } \\
\text { Idiom } \\
\text { Register }\end{array}$ & $\begin{array}{l}\text { Target } \\
\text { Idiom } \\
\text { Type }\end{array}$ & $\begin{array}{l}\text { Target } \\
\text { Idiom }\end{array}$ & $\begin{array}{l}\text { Target } \\
\text { Idiom } \\
\text { Register }\end{array}$ \\
\hline One-word & ضرَبية & Slang & Pure & shooters & Slang \\
\hline $\begin{array}{l}\text { Incomplete } \\
\text { Phrasal }\end{array}$ & التماسيح & Formal & Semi & $\begin{array}{l}\text { Crocodile } \\
\text { tears }\end{array}$ & Formal \\
\hline \multirow{2}{*}{$\begin{array}{l}\text { Complete } \\
\text { Sentence }\end{array}$} & رن براس كل & Formal & Semi & $\begin{array}{l}\text { made the } \\
\text { heads of } \\
\text { boys and } \\
\text { girls turn }\end{array}$ & Formal \\
\hline & 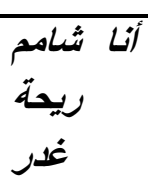 & Colloquial & Semi & $\begin{array}{l}\text { smell } \\
\text { betrayal }\end{array}$ & Colloquial \\
\hline
\end{tabular}

In her quest to achieve the most faithful as well as acceptable translation, the translator L. Youssef attempts to find TIs equivalent in both form and meaning to those of the SL. Nevertheless, pinning down a TI with similar constituent elements ordered in the same syntactic structure of the SI is not always readily doable, especially when the linguistic and cultural fabric of both languages are not quite close. Besides, the aspect of the contextual register and stylistic consideration are quite dissimilar in the ST itself between MSA and the spoken, colloquial CA. Therefore, rendering similar TT idiomatic segments in form and meaning is probable but not frequent.

Accordingly, in the Arabic semi idioms, the translator opts for translating them into equivalent TL idioms with nearly the same syntactic and lexical structures as well as the register of formality in the TT. For instance, ضَربية shooters carry the same lexical meaning with the same slang contextual usage. The phrasal idiom implying false feelings to beg sympathy دموع التماسبح Crocodile tears is retained 
lexically and syntactically in the TI. Likewise, form, meaning and register are kept intact in the TT in the complete-sentence idiom تدير رأس كل من بر/ها make the heads of boys and girl turn, by a nearly exact TI implying the same SI metaphorical meaning of 'dazzling beauty'. Although the previous examples may seem literally rendered, they do not seem awkwardly translated being employed as familiar idioms with the same associations and implications in both Arabic and English.

\subsubsection{Using an Idiom of Similar Meaning but Dissimilar Form}

\begin{tabular}{|c|c|c|c|c|c|}
\hline $\begin{array}{l}\text { Source } \\
\text { Idiom } \\
\text { Type }\end{array}$ & $\begin{array}{l}\text { Source } \\
\text { Idiom }\end{array}$ & $\begin{array}{l}\text { Source } \\
\text { Idiom } \\
\text { Register }\end{array}$ & $\begin{array}{l}\text { Target } \\
\text { Idiom } \\
\text { Type }\end{array}$ & $\begin{array}{l}\text { Target } \\
\text { Idiom }\end{array}$ & $\begin{array}{l}\text { Target } \\
\text { Idiom } \\
\text { Register }\end{array}$ \\
\hline \multirow[t]{2}{*}{ One-word } & خربوها & Slang & Pure & $\begin{array}{l}\text { They've } \\
\text { hit rock } \\
\text { bottom }\end{array}$ & Slang \\
\hline & كلبوش & Slang & Pure & $\begin{array}{l}\text { got } \\
\text { busted }\end{array}$ & Slang \\
\hline \multirow{5}{*}{$\begin{array}{l}\text { Incomplet } \\
\text { e } \\
\text { Phrasal }\end{array}$} & الحق حق & Colloquial & Pure & $\begin{array}{l}\text { Fair } \\
\text { and } \\
\text { square }\end{array}$ & Colloquial \\
\hline & تن تن وتتنون & Slang & Pure & $\begin{array}{l}\text { Chip } \\
\text { and } \\
\text { Dale }\end{array}$ & Colloquial \\
\hline & نائر ونئير & Colloquial & Pure & $\begin{array}{l}\text { cat and } \\
\text { mouse }\end{array}$ & Colloquial \\
\hline & السعادئر $\quad$ من & Colloquial & Semi & $\begin{array}{l}\text { over the } \\
\text { moon }\end{array}$ & Colloquial \\
\hline & حاضر الذهن & Formal & Semi & $\begin{array}{ll}\text { at } & \text { my } \\
\text { best } & \end{array}$ & Colloquial \\
\hline \multirow{2}{*}{$\begin{array}{l}\text { Complete } \\
\text { Sentence }\end{array}$} & عليهم عليهم seيهم & Colloquial & Pure & $\begin{array}{l}\text { Be a } \\
\text { fair } \\
\text { weather } \\
\text { friend }\end{array}$ & Colloquial \\
\hline & نجنته & Formal & Semi & $\begin{array}{l}\text { we } \\
\text { ticked } \\
\text { him off }\end{array}$ & Colloquial \\
\hline
\end{tabular}






This strategy entails replacing the SI by another TI, however, with different lexical and syntactic structure but with the same propositional meaning. For instance, the idiom كلبوش whose context of usage is apparently slang, implying the denotative meaning of 'get caught' or 'imprisoned'. However, the translator opts for not only conveying the semantic meaning, but for also retaining the level of formality, and chooses a slang TI equivalent got busted so as to have the same impact on the TR.

Such strategy is quite frequent in the L. Yousef's TT. In the phrasal SI تنتن و تنتون which is apparently culture-specific, implying 'two close inseparable friends', the translator opts for an equivalent culture-specific TI, to be well known in the TC and recognized by the TR like: Chip and Dale and similarly she does so with SI which denotes the ever-quarrelling friends نائر و نئبر cat and mouse. As for the ST full sentence idioms that are rendered as TL full sentence idioms, which although do not have the same constituent elements, they convey not only the propositional meaning and the same connotative impact, but also preserve the contextual register of formality or colloquialism like: دمر الثقى بقى You'll be here for your sins.

Besides, the translator attempts to decide on either pure or semi 
TI idioms, so as to keep the element of idiomaticity as much as she can to maintain the vividness, liveliness, culture-specificity and aestheticism of the original text. This is also apparent in many instances in the TT like: تحت أمرك at your beck and call (indicating readiness to follow orders) and غالى و الطلب رخيص whatever you say (showing willingness to help). It is quite notable that, although some of these semi idioms are used in both formal and colloquial registers, the translator is keen to keep the closest contextual usage of each one according to the situational milieu. For instance, تحت أمرك at your beck and call is employed in both varieties of the SL namely MSA and spoken colloquial CA to imply readiness of obedience and offering service. However, the context of usage in this instance is used in the spoken part, so it has colloquial hues that are aptly retained in the TI.

Moreover, the strategy of approximate substitution to meet cultural specificity is apparent in the following similar idiom with dissimilar form في ستين دانت تنفخ في قربة مقطوعة Good riddance banging her head against a brick wall. Such SL idioms bear cultural shades that may be peculiar to the Arabic culture in general and the Egyptian culture in particular, the former implying anger and the latter implying futility. Accordingly, the translator substitutes the lexical items that are quite culture-bound as قربة مقطوعة and قدية with others familiar to the English TR riddance and brick wall. For rendering them as they are would yield awkward incomprehensiveness in these contexts. Nonetheless, the translator goes for conveying the connotative, pragmatic meanings behind such SI, with equivalent TI conveying the same tinges of meaning in the pertinent register and relevant level of language. 
Rania Allam: Translating Idiomatic Expressions from Arab

6.1.3 Borrowing the Source Language Idiom

\begin{tabular}{|c|c|c|c|c|c|}
\hline $\begin{array}{l}\text { Source Idiom } \\
\text { Type }\end{array}$ & $\begin{array}{l}\text { Source } \\
\text { Idiom }\end{array}$ & $\begin{array}{l}\text { Source } \\
\text { Idiom } \\
\text { Register }\end{array}$ & $\begin{array}{l}\text { Target } \\
\text { Idiom } \\
\text { Type }\end{array}$ & $\begin{array}{l}\text { Target } \\
\text { Idiom }\end{array}$ & $\begin{array}{l}\text { Target } \\
\text { Idiom } \\
\text { Register }\end{array}$ \\
\hline One-word & عجبى & Colloquial & Literal & $\overline{A g a b i}$ & Colloquial \\
\hline \multirow{2}{*}{$\begin{array}{l}\text { Incomplete } \\
\text { Phrasal }\end{array}$} & الأبالسة & $\overline{\text { Slang }}$ & Literal & $\begin{array}{l}\text { son of the } \\
\text { devil }\end{array}$ & Slang \\
\hline & صر اصبير دماغ & Slang & Pure & $\begin{array}{l}\text { cockroach } \\
\text { high }\end{array}$ & Slang \\
\hline \multirow{3}{*}{$\begin{array}{l}\text { Complete } \\
\text { Sentence }\end{array}$} & الجو مغبم & Formal & Semi & $\begin{array}{l}\text { It's been } \\
\text { rather } \\
\text { foggy }\end{array}$ & Formal \\
\hline & دمى نشف & Colloquial & Literal & $\begin{array}{l}\text { my blood } \\
\text { was } \\
\text { curdled }\end{array}$ & Colloquial \\
\hline & رينا بيتر & Colloquial & Literal & $\begin{array}{l}\text { Rabena } \\
\text { Yestor. } \\
\text { May God } \\
\text { help me }\end{array}$ & Colloquial \\
\hline
\end{tabular}

Within the same line of retaining idiomaticity, the translator adopts a strategy of keeping the same constituents and meanings of the SI in the corresponding TI, even if resorting sometimes to transliteration. This is actualized in the SI عجبى Agabi, which would lose a lot of its propositional allegations if translated in words other than its original rendering. However, the translator explains its propositional meaning in a footnote for non-native TRs as Lo and Behold (a compensation strategy that is to be discussed later).

Other SIs are literally translated as the example in هي الكشرحة the morgue is not in need for more corpses. The meaning of this semi idiom can be inferred by the TR (the speaker has had enough). Nevertheless, translating it as (having enough) may have impaired the metaphorical effect, which is quite vivid and enriching. 
Similarly, the SI بن الأبالسة son of the devil can bear devilish meaning of cunning, scheming and shrewdness. The SI دمى نشف is translated meticulously as my blood was curdled which implies startling fright. Such SI can have many TI equivalents involving staggering dread like my blood run cold or jumped out of my skin. However, the translator opts for retaining the SL propositions.

\subsubsection{Translation by Paraphrase}

\begin{tabular}{|c|c|c|c|c|c|}
\hline $\begin{array}{l}\text { Source } \\
\text { Idiom } \\
\text { Type }\end{array}$ & $\begin{array}{l}\text { Sourc } \\
\text { e } \\
\text { Idiom }\end{array}$ & $\begin{array}{l}\text { Source } \\
\text { Idiom } \\
\text { Register }\end{array}$ & $\begin{array}{l}\text { Target } \\
\text { Idiom } \\
\text { Type }\end{array}$ & $\begin{array}{l}\text { Target } \\
\text { Idiom }\end{array}$ & $\begin{array}{l}\text { Target } \\
\text { Idiom } \\
\text { Register }\end{array}$ \\
\hline \multirow{2}{*}{ One-word } & غرزة & Slang & $\begin{array}{l}\text { Incomplet } \\
\text { e phrase }\end{array}$ & Opium den & $\begin{array}{l}\text { Colloquia } \\
1\end{array}$ \\
\hline & جدع & Colloquial & $\begin{array}{l}\text { Incomplet } \\
\text { e phrase }\end{array}$ & $\begin{array}{lr}a \quad \text { strong } \\
\text { personality }\end{array}$ & Formal \\
\hline \multirow{4}{*}{$\begin{array}{l}\text { Incomplete } \\
\text { Phrasal }\end{array}$} & سبعات فئى & Slang & Nonidiom & Endlessly & Formal \\
\hline & مالوشل & Colloquial & Nonidiom & $\begin{array}{l}\text { He was } \\
\text { quite witty }\end{array}$ & Colloquia \\
\hline & مفهوشة & Slang & Nonidiom & $\begin{array}{l}\text { physically } \\
\text { fragile }\end{array}$ & Formal \\
\hline & فلى جنابية & Colloquial & Nonidiom & $\begin{array}{l}\text { a few strict } \\
\text { words }\end{array}$ & Formal \\
\hline \multirow{2}{*}{$\begin{array}{l}\text { Complete } \\
\text { Sentence }\end{array}$} & أخماستات & Formal & Nonidiom & $\begin{array}{l}\text { I could not } \\
\text { tell } \\
\text { whether } \\
\text { this was a } \\
\text { dream or } \\
\text { reality }\end{array}$ & Formal \\
\hline & سلجمتهي & $\begin{array}{l}\text { Colloquia } \\
1\end{array}$ & Nonidiom & $\begin{array}{l}\text { Her } \\
\text { reputation } \\
\text { was } \\
\text { impeccable }\end{array}$ & Formal \\
\hline
\end{tabular}

As Baker (2018) indicates, such strategy is adopted in the case when the translated SI would not seem as natural and acceptable in the 
TT as it is in the ST. Therefore, in one-word instances like: a strong personality they are either related to the context of drug world غدزع or culture specific جرع or Therefore, it would be more illustrative to rephrase the meaning constituents; Opium (a type of drug) and den (a cave as more or less such places are like secret caves) as well as strong personality eloquently explains the contextual usage in which Salah the protagonist is describing one of his friends who possess a strong character. Transliterating SIs and then explaining them in footnotes, would be another option, which the translator actually does but in other ST instances that are either inexplicable or do not have an exact TL equivalent.

Other phrasal instances like: سبعات فى تمنيات endlessly are translated in a non idiomatic way, yet its TL rendition is appropriate to the context of driving the car loosely in the street. Similarly, the instances: مالوش حل he was quite witty كلمتين فى جن a few strict

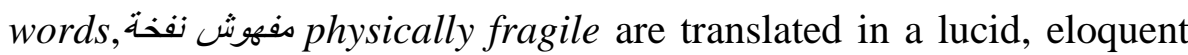
stylistic manner in which the SI constituents are explicitly elucidated to attain pragma-semantic clarity. Nonetheless, this strategy discards with the aesthetic, linguistic impact and the register level, as most paraphrasing TL segments are formal even if the SIs are not.

\subsubsection{Partial Translation of the Idiom}

\begin{tabular}{|c|c|c|c|c|c|}
\hline $\begin{array}{l}\text { Source Idiom } \\
\text { Type }\end{array}$ & $\begin{array}{l}\text { Source } \\
\text { Idiom }\end{array}$ & $\begin{array}{l}\text { Source } \\
\text { Idiom } \\
\text { Register }\end{array}$ & $\begin{array}{l}\text { Target } \\
\text { Idiom } \\
\text { Type }\end{array}$ & $\begin{array}{l}\text { Target } \\
\text { Idiom }\end{array}$ & $\begin{array}{l}\text { Target } \\
\text { Idiom } \\
\text { Register }\end{array}$ \\
\hline One-word & كلهم فقلى البيت & Slang & Literal & $\begin{array}{l}\text { Would pinch } \\
\text { things that } \\
\text { belonged to } \\
\text { any member } \\
\text { of the family }\end{array}$ & Slang \\
\hline $\begin{array}{l}\text { Incomplete } \\
\text { Phrasal }\end{array}$ & دم فتحى فتى & Colloquial & Semi & $\begin{array}{l}\text { The } \\
\text { responsibility } \\
\text { of Fathy's } \\
\text { life rests in } \\
\text { your hands }\end{array}$ & Colloquial \\
\hline
\end{tabular}




\begin{tabular}{|c|c|c|c|c|c|}
\hline & كبف الحرامية & Slang & Semi & $\begin{array}{l}\text { the dope of } \\
\text { thieves }\end{array}$ & Slang \\
\hline \multirow{2}{*}{$\begin{array}{l}\text { Complete } \\
\text { Sentence }\end{array}$} & ينفل بجلده الشاطر & Slang & Semi & $\begin{array}{l}\text { To be smart } \\
\text { enough to } \\
\text { escape this } \\
\text { catastrophe }\end{array}$ & Formal \\
\hline & 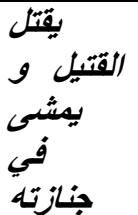 & Colloquial & Semi & $\begin{array}{l}\text { To kill a } \\
\text { man and } \\
\text { mourn him }\end{array}$ & Colloquial \\
\hline
\end{tabular}

This strategy entails replacing part of the SI by another TI, and the other part is paraphrased or elucidated by other lexical constituents, while rendering the same meaning implications. This is quite moving along the line of retaining idiomaticity. For instance, Wowhich means (steal belongings and money); the translator opts for using an idiomatic verbal group pinch to insinuate a childlike kind of stealing from family members as Salah, the hero, is the youngest pampered son. The verbal group pinch has an informal context of usage that is echoed in the slang CA verbal group بقلبهم Furthermore, دم فتحى فى رقبتك the SI is rendered partially as the TI life rests in your hands and partially as a paraphrasing segment The responsibility of Fathy's life perhaps to evade redundant idiomaticity that may sound portentous and pompous. The rendering of كيف dope might add a sense of idiomaticity to the idea of drug or narcotics that might not suit the slang register of the SL item.

Likewise, the SI ينفل بلده is transferred partially by the illustrative verb escape and illustrative nominal group catastrophe. However, this partial rendering does not retain the level of formality. Besides, the proverbial SI يقنل القتيل و بششى فى جنازته to kill a man and mourn him is partially explained and the other part is metaphorically rendered by the verb mourn. Such type of strategy is a blend of both paraphrasing and idiomaticity that may add some vibrancy to the TT. 
Rania Allam: Translating Idiomatic Expressions from Arab

6.1.6 Strategy of Compensation

\begin{tabular}{|c|c|c|c|c|c|}
\hline $\begin{array}{l}\text { Source Idiom } \\
\text { Type }\end{array}$ & $\begin{array}{l}\text { Source } \\
\text { Idiom }\end{array}$ & $\begin{array}{l}\text { Source } \\
\text { Idiom } \\
\text { Register }\end{array}$ & $\begin{array}{l}\text { Target } \\
\text { Idiom } \\
\text { Type }\end{array}$ & $\begin{array}{l}\text { Target } \\
\text { Idiom }\end{array}$ & $\begin{array}{l}\text { Target } \\
\text { Idiom } \\
\text { Register }\end{array}$ \\
\hline & حرام & Colloquial & Literal & $\begin{array}{l}\text { Haram, } \\
\text { ill- } \\
\text { begotten }\end{array}$ & Formal \\
\hline One-word & يا حلم & Colloquial & Literal & $\begin{array}{l}\text { You are a } \\
\text { dreamer, } \\
\text { Abdel- } \\
\text { Halim }\end{array}$ & Colloquial \\
\hline $\begin{array}{l}\text { Incomplete } \\
\text { Phrasal }\end{array}$ & ربنا بيستر & Colloquial & Literal & $\begin{array}{l}\text { Rabena } \\
\text { Yestor. } \\
\text { May God, } \\
\text { help me } \\
\end{array}$ & Colloquial \\
\hline $\begin{array}{l}\text { Complete } \\
\text { Sentence }\end{array}$ & زوبناها و & Slang & Semi & $\begin{array}{l}\text { We've } \\
\text { gone } \\
\text { overboard }\end{array}$ & Colloquial \\
\hline
\end{tabular}

This strategy entails omitting the SI and then compensating it in another place in the TT. This strategy is not common in A Quarter Gram. It appears in some idiomatic instances. For instance, the oneword attributive حرام which comes in a colloquial context has many religious hues that indicate an action or saying against the values and teaching of religion. However, in the narrative context it is describing money. Therefore, the translator opts for keeping the religious milieu of the idiomatic expression transliterated, while compensating for the ambiguity that may rise by paraphrasing the SI idiom just after its transliterated form by adding another TI attributive ill-begotten. The same goes to the phrasal SI رينا بيتر which is transliterated and then paraphrased later.

Another phrasal SI قلبه ميت is repeated more than once in the ST. Hence, it is translated as heartless to indicate absolute bravery and readiness to face perils to bring drug shots. However, in another ST segment it is discarded being repeated before in other parts of the TT. As for the complete sentence SI خربناها قوى it is repeated throughout 
the narrative ST several times and it is translated with idiomatic expressions like hit the bottom rock. In the context of the translational segment probed here it comes after the SI زودناها which nearly convey the same connotation of going so far. Thus the translator suffices to translate it once by another TI We've gone overboard which compensates the meaning of the SI.

\subsubsection{Translation by Omission of an Entire Idiom}

\begin{tabular}{|c|c|c|}
\hline Source Idiom Type & Source Idiom & Source Idiom Register \\
\hline One-word & مكلبظ & Slang \\
\hline \multirow{2}{*}{ Incomplete Phrasal } & حريقة سجاير & Colloquial \\
\hline & عملنا شغل & Colloquial \\
\hline Complete Sentence & مفيش فيه صريخ ابن بيومين & Colloquial \\
\hline
\end{tabular}

This strategy is resorted to when the translator feels that she can discard with rather repetitive ST idiomatic elements, or she can render the meaning with minimum words for stylistic reasons or space limits. For, the original novel is quite lengthy with more than 640 pages and the TR may suffer some distracting boredom, if it is rendered with the same size; as paraphrase, explanation or footnoting may yield an inept even more bulky TT. Omission in the previous examples is not bungled, doing no harm to the produced TT. For instance, the first مكلبط (chubby or plump) is considered a kind of reiteration in the ST segment هو بتهنع بزيادة الوزن أو مكلبظ بدنى أصح'the word 'overweight' aptly conveyed the meaning with little or no loss at all.

Likewise, the phrasal idiom حريقة سجاير is deleted as it is again a replicated explanation in the ST segment 'يشرب علب سجاير كل يوم', so deletion would not be drastic. As for عملنا شغل يوم it is in a context of describing the adventure of the الثنلة or the 'gang' with girls in the club, and how they become popular and exchanged phone numbers with beauties. Thus, it is an additional SI item describing their venturous popularity so it can be discarded. Furthermore, the other instances of omission of a whole idiom are due to the deletion of the 
whole ST paragraph or segment in which the SI occurs, for economic reasons as stated before or for avoiding redundancy. For instance, ' إيدى على كتفك ' (at your command) and' (help me and we can do it together) both are omitted as the whole ST paragraph is discarded, the first as it is a repeated explanation for the great generosity by which Salah and his dad are received by the royal family in KSA and the second is the deleted conversation between Salah and Mariam with whom he has a futile relationship. Most of the SI instances deletions are in segments or paragraphs concerning Salah's emotional relationship; perhaps as the translator's main concern is the idea of drug addiction and the young people struggle.

6.1.8 Translation of Non-idioms by Idioms

\begin{tabular}{|c|c|c|c|c|c|}
\hline $\begin{array}{l}\text { Segment } \\
\text { Type }\end{array}$ & $\begin{array}{l}\text { Source } \\
\text { Segment }\end{array}$ & $\begin{array}{l}\text { Source } \\
\text { Segment } \\
\text { Register }\end{array}$ & $\begin{array}{l}\text { Target } \\
\text { Idiom } \\
\text { Type } \\
\end{array}$ & $\begin{array}{l}\text { Target } \\
\text { Idiom }\end{array}$ & $\begin{array}{l}\text { Target } \\
\text { Idiom } \\
\text { Register }\end{array}$ \\
\hline \multirow{3}{*}{$\begin{array}{l}\text { One-word } \\
\text { Segment }\end{array}$} & يترياً & Colloquial & Pure & $\begin{array}{l}\text { Picked } \\
\text { on us }\end{array}$ & Colloquial \\
\hline & يا مجنون & Colloquial & Semi & $\begin{array}{lr}\text { Are } & \text { you } \\
\text { out } & \text { of } \\
\text { your } & \\
\text { mind } & \end{array}$ & Colloquial \\
\hline & واضح صريح & Formal & Semi & $\begin{array}{l}\text { Crystal } \\
\text { clear }\end{array}$ & Formal \\
\hline \multirow{2}{*}{$\begin{array}{l}\text { Incomplete } \\
\text { Phrasal } \\
\text { Segment }\end{array}$} & عامل مشاكل & Colloquial & Pure & $\begin{array}{l}\text { You are } \\
\text { wreaking } \\
\text { havoc }\end{array}$ & Colloquial \\
\hline & يا ل الحلول & Colloquial & Semi & $\begin{array}{l}\text { Mr } \\
\text { Know-it } \\
\text { all }\end{array}$ & Colloquial \\
\hline \multirow[b]{2}{*}{$\begin{array}{l}\text { Complete } \\
\text { Segment }\end{array}$} & إيه الوحش دهبر & Colloquial & Semi & $\begin{array}{l}\text { That's so } \\
\text { sad }\end{array}$ & Colloquial \\
\hline & لم بسهوليّة & Formal & Semi & $\begin{array}{l}\text { Had not } \\
\text { easily } \\
\text { blown } \\
\text { out }\end{array}$ & Formal \\
\hline
\end{tabular}

This strategy is not among the ones propounded by Baker (2018). However, it is among the semantic transformation proposed 
by Nida and Taber (1982). It is applied by the translator in ST segments which can tolerate to be transferred as TIs, so as to intensify the meaning and add liveliness to dialogic parts making them sound more TL oriented. ST translational segments like بتريا/ريا مجنون/واضح و صريح picked on us/ Are you out of your mind/ Crystal clear are translated idiomatically. They do not seem imposed as they are eloquently used as innate TL idioms employed in everyday language and contextualized in the dialogic part as part and parcel of the fabric of the novel.

Moreover, the phrasal ST segments با بتاع الحلول/عامل مشاكل كتبرة are both everyday SL normal segments. Yet, they are idiomatically rendered by the translator rhetorically adding eloquence by exaggeration through the former ST segment You are wreaking havoc and satiric, light impact through the latter Mr Know-it all.

إيه الخبر الوحش ده/ لم بير Likewise, the complete sentence segments are both translated idiomatically. It is quite normal in rather informal contexts to express sad news by the expression That's so sad. As for لم بير بسهولة , the translator opts for adding an amplifying, emblemising flavour to the TT segment by transferring it idiomatically Had not easily blown out. Such idiomatic translation appears to add to the target oriented acceptability of the TT.

\subsection{Using Notes and Consulting Informant}

This strategy is applied by the translator in rendering some culture-specific, local ST segments that may be incomprehensible to foreign TR. They are also applied to idioms or terms related to drugs and drug addiction. Being not that common for both the SL and the $\mathrm{TL}$ readers, they need some clarification and sometimes extensive explanation. The translator herself in the preface states that she needed to consult informants on matters related to drug terms. They range from translation experts like the great professor and scholar Mohammed Enani, to foreign, native speakers of English "who would read the translation as a foreign reader would" (L. Youssef, 2009, 
preface), so as to see how such drug terms can be coined in an eligible way for English native speakers. This attribute is given by the translator to Charles Butterworth and his daughter Gabriella Butterworth. The translator extend her gratitude to others, however, we suffice with the most effective consulting informants.

Footnotes are employed throughout the whole novel to explain language specific, culture based, or rather awkward, strange terms that need to be elucidated for the foreign TR. In this section, some instances of drug related terms with idiomatic tinges would be explained only, as they are the ones pertinent to the present study like: Kobaya (a glass used to trap smoke that can be inhaled), qirsh (an Egyptian piaster coin which weighed 12 or 13 grams, was used as a unit of measurement on one side of sensitive scale to weigh hashish) toot (a small marijuana cigarette), hashish stick (enormous joint) Khabour خابورin the original ST, farsha (a block of hashish), dorg (a drawer which has approximately 12 hagar(s) of hashish of course). However, this strategy is not to be included in the quantitative statistical analysis, as such terms are not linguistically embedded as idioms. Besides, they display little variation as all of them are transliterated and explicated in footnotes.

\subsection{Rhythmic Phrases}

There is another notable translation hindrance in A Quarter Gram, namely rhythmic phrases, E. Youssef employs them to add vividness', liveliness and mystical aesthetic value to the dialogue. Some of them are well phrased and retained in the TT like: اللى يتهور If you rash you crash, و ديعور

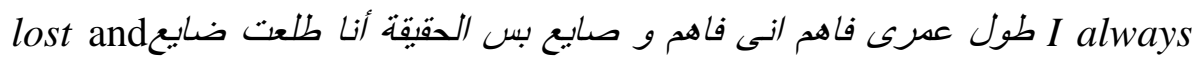
thought I was a man of the world, but in fact I'm lost in the world.

\section{Findings and Conclusion}

The previous qualitative analysis conducted on both the ST idioms and the TT ones to explore the strategies propounded in the eclectic model employed in the present paper and the frequencies of 
their occurrence yields the following results:

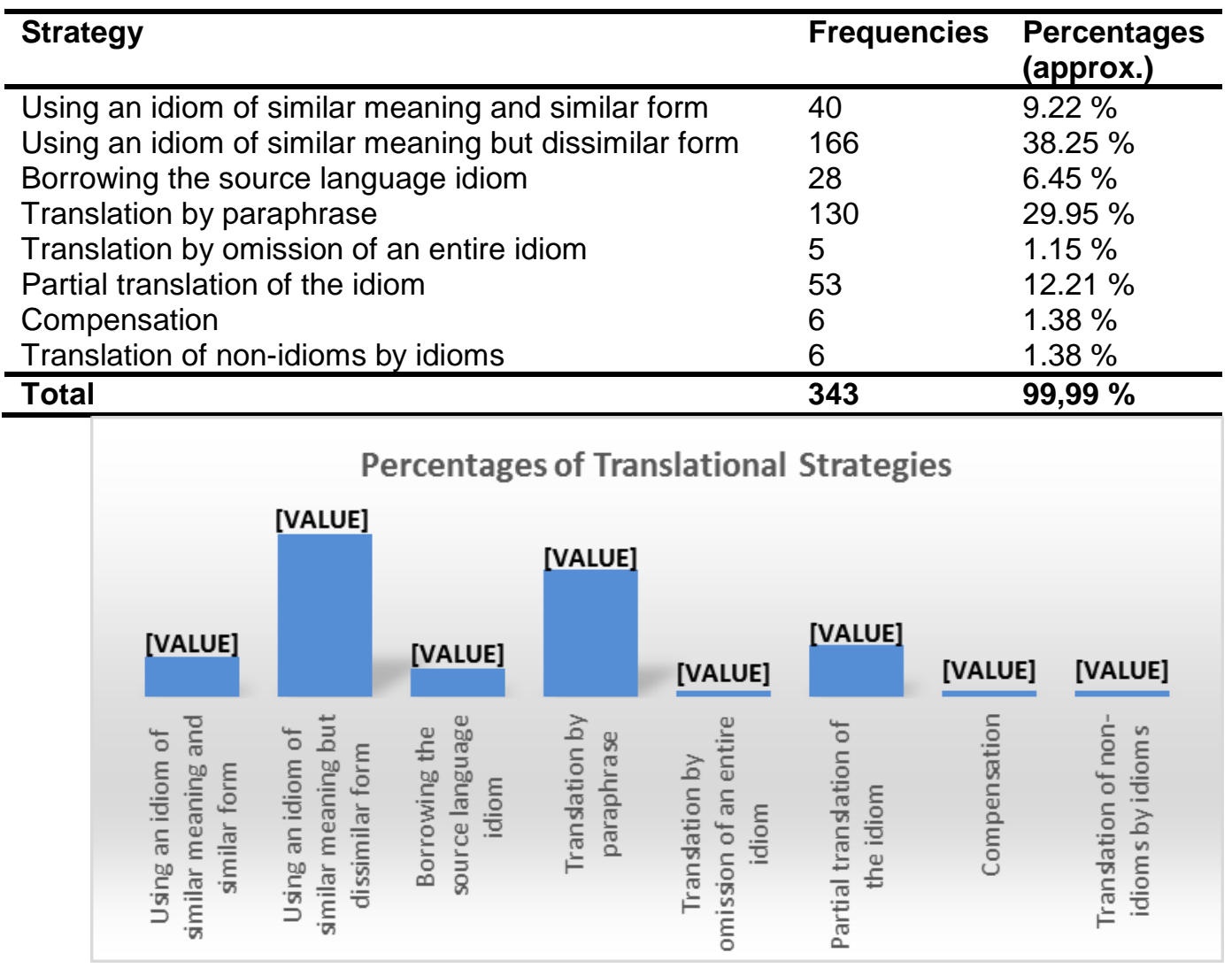

The previous analysis yields some results pertinent to the problem-solving strategies employed by the translator L. Youssef (2009) to overcome linguistic and cultural hindrances of idiomaticity. By applying primarily the manipulating translational strategies propounded by Baker (2018) and Nida and Taber (1982) to translate the syntactically classified ST idioms some inferences have been deduced.

The ST under study exhibits many idiomatic expressions that pose notable challenges for the translator. One of the difficulties lies in the culture specific peculiar features of the Arabic SIs. For instance, SIs like : بعبوك فى أزايز get bottled somewhere زيتنا فى دقيقنا it's all in the 


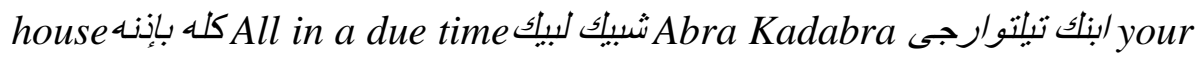
son was brought up on the streets are rendered using different strategies to overcome the ambiguity that may result from cultural differences. Strategies of using a TI with similar meaning and form, using a TI with similar meaning but dissimilar form, substituting a TI term familiar to the TR and paraphrasing the SI propositional meaning are used respectively.

Another difficulty lies in idioms which are phrased as proverbs. Such ST segments are employed by the author idiomatically like: اللى بيته من إزاز ما بحدف الناس بالطوب People who live in glass houses

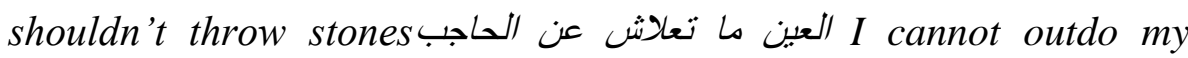
superior. The translator sometimes borrows the same structure and meaning as in the first example as the metaphor can be comprehended by the foreign TR and employs an explanatory, idiomatic TT segment, actualized by the verb outdo and the nominal group my superiors.

Besides, there is a difficulty which lies in employing two varieties of Arabic in the ST, namely MSA and CA with different levels of formality that should be taken into consideration. The SIs manifest various levels of formality like; بلا ضابط أو رابط a complete lack of discipline أنا اديتك أعلى درجات الأمل I gave you high hopes بلان immature geeks. The translator tries to cope with the three levels of formality; formal MSA, colloquial CA and slang CA in the three idiomatic translational segments using partial idiomatic rendering in the three examples in order to keep the closest formality level of Arabic varieties.

The analysis of the TT has shown that strategies proposed by Baker (2018) are quite valid in probing the translation of idiomatic expressions in the produced TT. They help exhibit the translational decision opted for by the translator. She has also applied mostly a strategy suggested by Nida and Taber (1982) (translating nonidiom with idioms). Al-Shawi and Mahadi (2012)'s strategies of using notes and consulting informant are also used but not calculated in the 
statistical analysis for the reasons already mentioned.

The most frequently used strategy is using an idiom of similar meaning but dissimilar form with a percentage of $\mathbf{3 8 . 2 5 \%}$. This shows that the translator is trying her best to retain the idiomaticity of the ST, retaining the same formality level as much as possible except in a few examples in which she opts for transferring the connotation more than the formality level.

In addition, the translator employs the strategy of using an idiom of similar meaning and similar form with a percentage of $\mathbf{9 . 2 2 \%}$. The percentage is not that high, as the incidence of finding an equivalent idiom in meaning and form between two different languages as Arabic and English is not that common. The translator also retains the idiomaticity of the ST by applying the strategy of borrowing the SL idiom with a percentage of $6.45 \%$. It is quite obvious that, the translator does not resort to retain the same semantic and syntactic constituents of the Arabic SI except when there is no exact TI idiom that may meticulously fit in the TT translational context. Besides, keeping the same SI into the TT is tackled in a manner that may not be awkward to the TR culture.

When the translator feels that carrying on the whole ST translational segment may render a faithful yet unacceptable translation, she employs the strategy of partial translation of the idiom with $\mathbf{1 2 . 2 1 \%}$. This can be detected in some instances like the ones related to the context of drug addiction: أنت ضارب ضرب مبرح You shot up high, she resorts to the partial delivering of the SI as a compromising strategy.

Within the line of maintaining the ST idiomatic expressions with all its aesthetic hues, the translator employs the strategy of translating non-idioms by TI idioms even in some non-idiomatic ST segments by $\mathbf{1 . 3 8 \%}$. Although the frequency of this strategy is very low, it is employed when the translator thinks that such TIs would serve the best in conveying propositional, connotative meaning and aesthetic, 
vivid impact in the TT.

Within the fabric of the TT some TIs are omitted altogether with the percentage of $\mathbf{1 . 1 5 \%}$. Most of these SIs are among entire deleted paragraphs. This may be done to reduce the bulky volume of the novel. This frequency is the least among the used strategies, exhibiting the translator keenness to maintain the idiomatic tinge of the ST. Parallel to this strategy, the strategy of compensation is applied by $\mathbf{1 . 3 8 \%}$ so as to make up for some of the loss that may have been caused by omission.

The second most frequently used strategy is translation by paraphrase with a percentage of $\mathbf{2 9 . 9 5 \%}$. This strategy is employed as an explanatory substitute for the SI. This is used when the translator does not pin down an equivalent TI for the SI. This strategy although not moving along the same stream of retaining idiomaticity, it does not have a drastic effect on the liveliness, vividness, metaphorical impact implied by idioms. This is due to the fact that the ST is 640 pages prolific with many idioms, thus transferring about $\mathbf{3 0 \%}$ in an explanatory from would not harm the overall artistic effect. Besides, if the whole strategies that retain idiomaticity are calculated, they would constitute $\mathbf{6 8 . 8 4 \%}$ of the total employed strategies. This percentage is approximately $\mathbf{7 0 \%}$, which is a high percentage that reflects the translator's dedication to the idiomaticity of the ST, with all its implications.

Despite the fact that translating idioms is considered one of the most exigent translational tasks, especially the problem of nonequivalence which appears between two dissimilar languages, the translator is able to retain about $\mathbf{7 0 \%}$ of the ST idiomaticity with their register of formality so as to produce a premium TT product. This implies a thorough understanding of the languages involved. The translator succeeds in transferring most of the Arabic SIs into English TIs. Furthermore, linguistic, cultural, social and aesthetic features implied by either formal or informal SIs help depict a culture-bound, 
realistic humane picture of the characters in the ST. The aptly conveyed TIs help rendering the characters equally vivid and realistic in the TT. Such effects are actualized by the strategies adopted by the translator who attempts assiduously to hold her responsibility of conveying the ST idiomatic, situational occurrences as faithfully and acceptably as possible.

Eventually it can be inferred that, the issue of translating idioms is considered an inexhaustible topic in the field of translation studies. Therefore, it is recommended that in future research, this issue can be examined in other novels with different themes that can yield reliable illuminating results. For instance, the modern Egyptian novels for young writers; males or females exhibit such kind of linguistic diversities between the two varieties of Arabic that may be quite a fertile subject to probe. Moreover, there are other dialects of Arabic other than the Egyptian; the Levant accent, the gulf area accent as well as the North African one. Such varieties can be realms of conducting studies especially comparative ones. 


\section{References}

Abou el Magd, N. (2008). Bestseller lays bare drug abuse in Egypt. The National World. https://www.thenational.ae/.November 3, 2008 04:00 AM.

Abou-Zalal, E. A. (2007). التعابير الاصطلاحية بين النظرية و التطبيق. Volume 1, 1st Edition. Cairo: Ajiyal.

Aldahesh, A. Y. (2013). On idiomaticity in English and Arabic: A cross linguistic study. Academic Journals, Journal of Language and Culture. 4(2), 23-29. DOI: 10.5897/JLC2013.02202013

Al-Dyn, H. K. (1985). Idiomatic Expressions: A Study of the Root and Concept . Cairo: Anglo Press.

Ali, H. I. H. \& Al- Rushaidi, S. M. S. (2016). Translating idiomatic expressions from English into Arabic: Difficulties and strategies. Arab World English Journal (AWEJ) 7(4), 187-201. DOI: https://dx.doi.org/10.24093/awej/vol7no4.13

Almahmood, G. A. (2014). Effects of Situational and Cultural Context on understanding Idiomatic Expressions in Najdi Dialect. (Doctoral dissertation thesis). The University of Leeds. Retrieved from: https://www.google.com/url?sa=t\&rct=j\&q=\&esrc=s\&source=web\&cd $=1 \&$ ved=2ahUKEwiCh9Grsq7fAhVHKFAKHbNuBjoQFjAAegQIBxA C\&url=http\%3A\%2F\%2Fetheses.whiterose.ac.uk\%2F9061\%2F1\%2FG hassan\%2520Almahmood\%2520Student $\% 2520$ ID\%2520200439654\%2 520Thesis.pdf\&usg=AOvVaw0ZDUNiEXFM-jbmp-X6P3Z2

Al-Shawi, M. A. \& Mahadi, T. S. T. (2012). Strategies for translating idioms from Arabic into English and vice versa. AMARABAC Journal of American Arabic Academy for Sciences and Technology, 3(6), 139147.

Retrieved

from:

https://www.google.com/url?sa=t\&rct=j\&q=\&esrc=s\&source=web\&cd

$=1 \&$ ved $=2$ ahUKEwjJu-

Tfsq7fAhVJIlAKHeaNDi0QFjAAegQICRAC\&url=http\%3A\%2F\%2F www.amarabac-

magazin.com\%2Ffileadmin\%2Fimages\%2Fpdfs\%2FAMARABAC_3-

6_139-147.pdf\&usg=AOvVaw1bBY-zbhRf43AkapwcqOH3

Bahumaid, S. (2010). Strategies of translating idioms in English-Arabic Dictionaries. International Journal of Arabic-English Studies (IJAES), 11, 101-126. Retrieved from: https://www.google.com/url?sa=t\&rct=j\&q=\&esrc=s\&source=web\&cd $=1 \&$ ved=2ahUKEwik9JjUta7fAhXJZ1 AKHU0aDS0QFjAAegQIChAC \&url=http $\% 3 \mathrm{~A} \% 2 \mathrm{~F} \% 2 \mathrm{Fwww} . \mathrm{ijaes}$.net $\% 2 \mathrm{FArticle} \% 2 \mathrm{FFulTText} \% 2 \mathrm{~F} 9 \%$ 3Fvolume\%3D11\%26issue\%3D1\&usg=AOvVaw3LYILblhqHrhOuCrBJyPL 
Baker, M. (2018). In Other Words: A Coursebook on Translation, $3^{\text {rd }}$ edition. Oxon: Routledge.

Carine, M. (2005). Idioms. In P. Strazny (Ed.), Encyclopedia of Linguistics Vol. I, (pp. 494-495). New York: Fitzroy Dearborn. Retrieved from: http://www.gigapedia.com

Crystal, D. (2008). A Dictionary of Linguistic and Phonetics. 6th Edition. Malden: Blackwell Publishing.

Davies, M. G. (2004). Multiple voices in the translation classroom: activities, tasks and projects. Amsterdam and Philadelphia: John Benjamins.

Dweik, B. \& Abu Shakra, M. (2011). Problems in translating collocations in religious texts from Arabic into English. The Linguistics Journal,5 (1),5-41. Retrieved from:

https://www.google.com/url?sa=t\&rct=j\&q=\&esrc=s\&source=web\&cd $=1 \& \mathrm{cad}=$ rja\&uact $=8 \&$ ved $=2$ ahUKEwjJo4nIva7fAhXILFAKHevxBjM QFjAAegQICRAC\&url=https\%3A\%2F\%2Ffiles.eric.ed.gov\%2Ffulltex $\mathrm{t} \%$ 2FED510365.pdf\&usg=AOvVaw1W5wdYAGn4Y2FqCMBrWARC

Dweik, B. S. \& Thalji, M. B. (2016). Strategies for translation proverbs from English into Arabic. Academic Research International 7(2), 120-127. Retrieved from: www.savap.org.pk 120 www.journals.savap.org.pk

Elgobshawi, A.E. (2018). Opaque idioms in Arabic and English: A perspective analysis of their semantic anomaly. Journal for the Study of English Linguistics. 6(1), 37-46. DOI: 10.5296/jsel.v6i1.13207

Fernando, C. (1996). Idioms and Idiomaticity. Oxford: Oxford University Press.

Funtek, E. (2015). Idiom Comprehension in English as a Second Language. (B.A. thesis). Retrieved from: University of Rijeka.

Ghazala, H. (2003). Idiomaticity between evasion and invasion in translation: Stylistic, aesthetic and connotative considerations. Fédération des Traducteurs (FIT) Revue Babel, 49(3), 203-228. DOI: 10.1075/babel.49.3.03gha

Glucksberg, S. (2001). Understanding Figurative Language: From Metaphors to Idioms. New York: Oxford University Press.

Howwar, M. (2013). Seeking the nature of idioms: A socio-cultural study in idiomatic English and Arabic meanings. International Journal of Scientific and Research Publications (IJSRP), 3(2), 1-3. Retrieved from:

https://www.google.com/url?sa=t\&rct=j\&q=\&esrc=s\&source=web\&cd

$=1 \&$ ved $=2$ ahUKEwiivd 2 -

wq7fAhWRLFAKHb3rDR0QFjAAegQIBxAC\&url=http\%3A\%2F\%2F 
www.ijsrp.org\%2Fresearch-paper-0213\%2Fijsrp-

p1473.pdf\&usg=AOvVaw0ZkfgGOmb-dq5upb8J8JFz

Ifill, T. (2002). Seeking the nature of idioms: a study in idiomatic structure. Ms, Haverford Retrieved from https://www.google.com/url?sa=t\&rct=j\&q=\&esrc=s\&source=web\&cd $=3 \&$ cad $=$ rja $\&$ uact $=8 \&$ ved $=2$ ahUKEwi29ZjrpbPfAhWFEVAKHUtJDb 8QFjACegQIAhAC\&url=http\%3A\%2F\%2Fwww.ijsrp.org\%2Fresearch -paper-0213\%2Fijsrp-p1473.pdf\&usg=AOvVaw0ZkfgGOmbdq5upb8J8JFz

Irujo, S. (1986). "Don't put your leg in your mouth: transfer in the acquisition of idioms in a second language." Tesol Quarterly, 20 (2), 287-301. Retrieved from: https://www.jstor.org/stable/i285060

Kavka, S. \& Zybert, J. (2004). Glimpses on the history of Idiomaticity Issues, SASE J. Theor Linguist. 1(1), 54-66. Retrieved from: http://citeseerx.ist.psu.edu/viewdoc/summary?doi=10.1.1.565.1895

Kavka, S. (2003). A Book on Idiomatology. Žilina: EDIS.

Klaudy, K. (2003). Languages in Translation. Budapest: Scholastica.

Kovacs, G. (2016). About the definition, classification, and translation strategies of idioms. Acta Universitatis Sapientiae, Philologica, 8 (3), 85-101. DOI: 10.1515/ausp-2016-0033

Kvetko, P. (2009). English lexicology. Theory and practice. Trnava: Univerzita Cyrila Metoda.

Maxos, H. (2003). The Arabic idioms; the Art of Speech-Arabic Idioms Chapter, Damascus: Damascus Press.

McPherron, P. \& Randolph, P.T. (2014). Cat Got Your Tongue?: Recent Research and Classroom Practices for Teaching Idioms to English Learners Around the World. Maryland: TESOL Press.

Mezmaz, M. (2010). Problems of Idioms in Translation Case Study: First Year Master. (Master Thesis). Mentouri University Constantine. Retrieved from: https://bu.umc.edu.dz/theses/anglais/MEZ1146.pdf

Moon, R. (1998). Fixed Expressions and Idioms in English: A Corpus-Based Approach. Oxford: Clarendon Press.

Newmark, P. (1988). A Textbook on Translation. New York: Prentice Hall.

Nida, E. A., \& Taber, C. R. (1982). The Theory and Practice of Translation. Leiden: Brill.

Oualif, M. (2017). Translating idiomatic expressions from English into Arabic: Difficulties and strategies. World English Journal for Translation \& Literary Studies, 1(3), 22-31. DOI: http://dx.doi.org/10.24093/awejtls/vol1no3.2

Saberian, N. \& Fotovatnia, Z. (2011). Idiom Taxonomies and Idiom 
Comprehension: Implications for English Teachers, Theory and Practice in Language Studies, 1(9), 1231-1235. DOI:10.4304/tpls.1.9.1231-1235

Salim, J. A. \& Mehawesh, M. (2013). Color idiomatic expressions in the translation of Naguib Mahfouz's novel "The Thief and the Dogs": A Case Study. International Journal of English Linguistics, 3 (4), 107116. DOI:10.5539/ijel.v3n4p107

Youssef, E. (2008). A Quarter Gram. ربع جرام. Cairo: AL Dar Al-Masraya Al-Lobnanya.

Youssef, L. (2009). A Quarter Gram. Cairo: Montana Studios. 